\title{
Legal Protection of Geographical Indications in Indonesia from the Perspective of UU Number 20, 2016 concerning the Trademarks and Geographical Indications
}

\author{
Rani Pajrin ${ }^{1}$, Jamal Wiwoho², Moch. Najib Imanullah ${ }^{3}$ Pujiyono ${ }^{4}$ \\ \{ranipajrin@ymail.com ${ }^{1}$,jamalwiwoho@gmail,com ${ }^{2}$, najibImanullah@gmail.com ${ }^{3}$, \\ pujiyono@gmail.com $\left.{ }^{4}\right\}$
}

Program Doktor Ilmu Hukum, Universitas Sebelas Maret Surakarta, Jl. Ir. Sutami 36 A Surakarta, Indonesia ${ }^{1,2,3,4}$

\begin{abstract}
The purpose of this research is to find out the legal protection of geographical indications from the perspective of the Geographical Indication Law in Indonesia. Indonesia has many potentials for biodiversity. There are several regional products in Indonesia have been known by international markets so that they have a high economic value, which needs to be followed by legal protection. Indonesia has ratified several international conventions into Laws, including the TRIPS Agreement, the Convention on Biological Diversity, the Treaty on Plant Genetic Resources for Food and Agriculture (TPGRFA) which should protect all potential Geographical Indications Indonesia at the level of international trade. The research method in this scientific paper was normative legal research using some approach, namely: Statute Approach, Conceptual Approach, and Comparative Approach. Intellectual Property Right is part of human rights, which included in the economic, social, and cultural fields. In Indonesia, the regulation and legislation concerning HKI have been changed several times. The latest laws and regulations are as follows: UU Number 20, 2016, concerning the trademarks and Geographical Indications. Geographical indications are a sign that indicates the area of origin of an item or product due to geographical, environmental factors including natural factors, human factors or a combination of these two factors which provide certain reputation, quality, and characteristics on the goods or products produced. Legal protection is divided into preventive legal protection and repressive legal protection.
\end{abstract}

Keywords: Legal Protection, Geographical Indications, Law, Indonesia

\section{Introduction}

Indonesia is an archipelagic country located in the tropical region between the Asian Continent and the Australian Continent and between the two oceans, pacific and the Indian Ocean.[1] The area of Indonesia is 9 million $\mathrm{km}^{2}$, which consists of 7 million $\mathrm{km}^{2}$ of sea and 2 million $\mathrm{km} 2$ of land or islands.[2] The total of islands in Indonesia is 16,056 registered in the United Nations in 2018.[3] Each island has its characteristics and advantages.

Besides, Indonesia is an archipelagic country, Indonesia is known as an agricultural agrarian country, because the majority of the livelihoods of people in Indonesia are as farmers or working in the agricultural sector. In 2010 , the total population in Indonesia was 238.5 million and, in 2035 , it was projected to be 305.6 million population. From these data, the people who 
work in the agricultural sector are 38.07 million people.[4] The labor sector is in the second rank, which is as much as 34.6\%.5 The agricultural industry is vital for the economy of Indonesia because it is the basis for economic development.

In this agricultural sector, Indonesia has a lot of potential from its biodiversity. Indonesia has $25 \%$ of the species of flowering plants globally and the seventh with a total number of 20,000 species, and $40 \%$ as endemic plants or as plants that grow originally in Indonesia.[5] In this type of fern, 4,000 species are found in all regions in Indonesia. For rattan plants, there are 332 consisting of 86 species of genera daemonorops and 204 species of genera calamus. Indonesian medicinal plants have 20,000 species that are useful as medicinal plants. Indonesia is one of the centers of Vavilov, which is a distribution center for genetic plants for various plants such as bananas, nutmeg, cloves, durian, and rambutan. In terms of forest sector in Indonesia, Indonesia has the highest diversity of palm trees in the world; there 400 species of meranti, 122 species of bamboo species from 1200 that grow on the Earth.[6]

If it is written in detail, there is a lot of potential biodiversity in Indonesia. There are still many species whose genetic content is unknown, so that it causes not all of them to be commercially utilized. Agricultural development in Indonesia leads to the fulfillment of food and domestic industries, increasing exports and farmer income, expanding employment opportunities, and encouraging equity.[7] Several regional products in Indonesia have been known by the international market they have high economic value and need to be followed by legal protection to be able to protect these commodities from the practice of unfair competition in trading.[8]. Some commodities in Indonesia, there are several examples of 45 essential types of drugs found in the United States derived from plants, and 14 types of them are from Indonesia, such as vines, which function as cancer drugs. In Japan, there are also registered patents on drugs whose dangers are from biodiversity and traditional Indonesian knowledge.[9] In addition, several coffee commodities which the geographical indications are claimed by other countries, such as gayo coffee from Gayo District, Aceh Province. A company from Amsterdam, Holland Coffee B.V., officially registered and claimed gayo coffee as their trademark.[10] There is a similar case, where the company from Japan Key Coffee Co. registered the Toraja brand in 1976 as their trademark. [11]

Some foreign companies' trademarks use regional names from Indonesia, for example, the coffee brand, toarcotoraja by key coffee co, then the Avancetoraja brand by an avance trading co, which both companies are from Japan. Likewise, Gayo coffee from Aceh, a Dutch company Holland Coffee BV has used the Gayo Mountain trademark as their trademark, and several other cases of the use of geographical indications. Indonesia has ratified several international conventions into Laws, including the TRIPS Agreement, the Convention on Biological Diversity, the Treaty on Plant Genetic Resources for Food and Agriculture (TPGRFA), which should protect all potential Geographical Indications Indonesia at the level of international trade. In fact, Indonesia has UU Number 20, 2016 concerning the trademarks and Geographical Indications. For this reason, this paper provides a legal protection analysis of commodities that have the potential to have geographical Indications in Indonesia from the Perspective of UU Number 20, 2016 concerning the trademarks and geographical indications. So, in this research has the following problem formulation, How is the legal protection in the field of geographical indications in Indonesia? 


\section{Methodology}

The research method in this scientific paper was normative legal methods using some approaches, namely: Statute Approach, Conceptual Approach and Comparative Approach. The Primary raw materials used in reviewing this research were: the 1945 Constitution, UU Number 20, 2016 concerning the trademarks and geographical indications, Convention on Biological Diversity, Treaty on Plant Genetic Resources for Food and Agriculture (TPGRFA), TRIP's Agreement, Intergovernmental on Genetic Resources, Traditional Knowledge and Folklore (IGC-GRTKF), UDHR 1948, ICCPR, ICESCR, and other legal materials, namely studies relating to legal protection of intellectual property right and geographical indications. The above legal materials were analyzed and presented using qualitative descriptive analysis techniques. In obtaining data to be written in this research, the authors used several techniques in analyzing the data. First literature studies, including collecting books on the traditional protection of geographical indications. Second, a review the analysis of laws and regulations that applied in Indonesia specifically concerning the protection of Intellectual Property Rights. Also, to examine some international conventions relating to Intellectual Property Rights, especially in traditional knowledge, which includes the protection of biodiversity and local wisdom in Indonesia.

\section{Finding and Discussion}

\subsection{Legal Protection of Geographical Indications in Indonesia}

After the passing of the law number about the brand and geographical indications, there is a change in the regulation. no one has examined the legal protection of geographical indications seen from the regulatory aspects as well as related international treaties. The law can be used to realize protection that is not only adaptive and flexible, but also predictive and anticipatory.[12] The law predicts things that will happen in the future, with the law's aim to be able to anticipate them. This is important because there are so many potential natural resources of biodiversity of Indonesia that need to be protected by law. According to Muchsin, legal protection is a matter that covers traditional subjects through the prevailing rules and regulations and enforce its implementation by a sanction. Legal protection can be divided into two, namely:1) Preventive Legal Protection, is provided by the Government to prevent before the violation. This is contained in laws and regulations to prevent a breach and provide signs or limitations in responsibility. 2) Repressive Legal Protection, is the absolute protection in the form of sanctions, such as fines, imprisonment, and additional penalties, which are given if a dispute has occurred or an offense has been committed.[13] Intellectual Property Rights are part of human rights, which are included in the economic, social, and cultural fields. In principle, intellectual property right is attached to a person, without registration to the state. This is in line with Article 63 of UU Number 20, 2016 concerning the trademarks and indications where indications are protected without registration obligation or declaratively as a sign indicating the origin of the right goods and/or services and are used in trade.

HKI grouping, first industrial property rights include: patent, trademark, design, design the integrated industrial layout. The second is copyright, which provides protects for scientific writing, literary and artistic work. $16 \mathrm{HKI}$ is a form of effort to protect the inventor through a monopoly right given by law to obtain economic benefits from its invasion (all of their discovery).[14] In Indonesia, there are several changes in the regulation of HKI. The latest laws 
and regulations are as follows: UU Number 20, 2016 concerning the trademarks and geographical indications, UU Number 13, 2016 concerning patents, UU Number 28, 2014 concerning copyright, UU Number 30, 2000 concerning trade secret, UU Number 32, 2000 concerning integrated circuit networks, UU Number 31, 2000 concerning industrial design. Geographical indications, according to UU Number 20, 2016 concerning the trademarks and geographical indications is a sign that indicates the area of origin of an item and/or product due to geographical, environmental factors including natural factors, human factors, or a combination of these two factors providing reputation, quality, and specific characteristics of goods and/or products produced.

According to WIPO (World Intellectual Property Organization), geographical indications are signs used in products with a specific geographical origin and have a quality or reputation caused by its head. To a have function as a geographical indication, a sign must identify a product originating from a particular place. Also, the quality characteristics, or reputation of the product must be basically due to the area of origin. Because the rate depends on the geographical production site, there is a clear relationship between the product and the original production site. [15] Geographical indications are one of the regimes of intellectual property rights that need to be protected and developed. especially in agrarian and archipelagic countries, such as Indonesia. Potential geographical indications in Indonesia can come from natural factors, some of them are coffee commodities. The Biodiversity Convention has been ratified by Indonesia through UU No. 5, 1994, concerning the Ratification of the Biodiversity Convention. The proposed proposal is made to include some important aspects related to access of genetic resources in the provision of intellectual property rights: as it is mentioned that: the birth of the material/material used (source of birth), attach proof that the previous researchers have adequately informed the competent authorities/ parties in the appropriate place (prior informed consent), and completed it with a benefit-sharing agreement.

In 2009, Indonesia had registered a Geographical Indication on WIPO (World Intellectual Property Organization). We can see in the following table:

Table 1.

\begin{tabular}{clcl}
\hline No & \multicolumn{1}{c}{ Field } & total & \multicolumn{1}{c}{ Information } \\
\hline 1 & Agriculture/ Crops & 46 & 19 Coffee Products \\
2 & Forestry & 1 & Sumbawa Honey \\
3 & $\begin{array}{l}\text { Fishery/ } \\
\text { Products }\end{array}$ & 2 & Sidoarjo Smoked Milkfish and Bali Amed Salt \\
4 & Livestock & 1 & $\begin{array}{l}\text { Sumbawa Horse Milk } \\
5\end{array}$ \\
Craft & 4 & $\begin{array}{l}\text { Jepara Carving Furniture Crafts, Grinsing Bali Weaving, } \\
\text { Silk Weaving Sikka Weaving Manders }\end{array}$ \\
source: & www.WIPO.int international & organization in the field of intellectual property rights
\end{tabular}

\subsection{Geographic Indication Rights Registration Process}

To register a product with Geographical Indications in Indonesia, by the Trademark Law and Geographical Indications, the application made is submitted to the Minister of Law and Human Rights of the Republic of Indonesia. UU Number 20, 2016 concerning the trademarks and geographical indications, which has some limitations. There are two institutions can register their geographic indication rights, namely: 
1) An institution that represents the community in a particular geographic area that proposes product in the form of:

- natural resources;

- handicraft items;

- industrial results.

2) Provincial or district government/city-regional government. This is regulated in Article 53, Paragraph 5 of UU No. 20, 2016 concerning the trademarks and geographical indications. In providing protect for products that have prospects to be protected, the state guides to obtain a geographical indication certificate. Its, improvement is regulated in Article 70 of UU No. 20, 2016 concerning the trademarks and geographical indications, namely:

- Preparation for the need for requirements for Requesting Geographical Indications;

- Application for the registration of Geographical Indications;

- Utilization and commercialization of Geographical Indications;

- Socialization and understanding of the protection of Geographical Indications;

- Mapping and inventory of potential Geographical Indications products;

- Training, and mentoring;

- Monitoring, evaluation, and coaching;

- Legal protection; and

- Facilitate the development, processing and marketing of goods and/or products of Geographical Indications.

The existence of UU Number 20, 2016 concerning the trademarks and geographical indications, in line with the international convention on genetic plant resources for Food and Agriculture, in which Article 9.2 regulates the rights of farmers, namely:

- Protection of traditional knowledge relevant genetic plant resources for food and agriculture;

- The right to participate equally in the distribution of benefits resulting from the utilization of genetic plant resources for food and agriculture; and

- The right to participate in decision-making, at the national level, regarding to some matters relating to the conservation and sustainable use of plant genetic resources for food and agriculture.

The communal protection of intellectual property rights has indeed happened because the existence of the TRIPS agreement scheme is rather ignored. After all, the TRIPS agreement is more individualistic. Although the initial indication right is without the need for registration but in the context, it is necessary to have protection that covers four things, namely:

- The importance of protection,

- The intellectual rights regime as an internationally recognized protection system

- What the most appropriate regime to protect the rights of local Indonesian people is, and

- Efforts made by the Indonesian Government in the future.

Legal protection through UU Number 20, 2016 concerning the trademark rights and geographical indications is preventive or repressive protection or action. If it is associated with the rule of law, it means that Indonesia provides legal defense based on fairness, usefulness, and 
the existence of legal certainty. There are two other models of security, according to Muladi and Barda Nawawi Arief, namely fulfill the procedural right and service model. If on a procedural model, the victim plays an active role in the criminal and civil justice process. If it is in the criminal justice model, is done through the National Police of the Republic of Indonesia and the Civil Servant Investigator in the investigation process. The second phase of prosecution in the Prosecutor's office, and the process of verification at the District Court. In civil cases, by the mandate of UU Number 20, 2016 concerning the trademark rights and geographical indications, the justice process at the Commercial Court which is a sub-section of the District Court. In the second is the service model, emphasizing the provision of compensation in terms of providing compensation to the disadvantaged victim.

The implementation of an exemplary system of intellectual property rights, does not only require implementing the legislation in the field of appropriate intellectual property rights, but also it needs to be supported by the administration, law enforcement, and an optimal socialization program on intellectual property rights. In law protection, it is done through by registering of geographical indications in Indonesia, which regulates in Government Regulation Number 51, 2007 about geographical Indications. To be more explicit in understanding it step by step, it can be seen in the chart below:

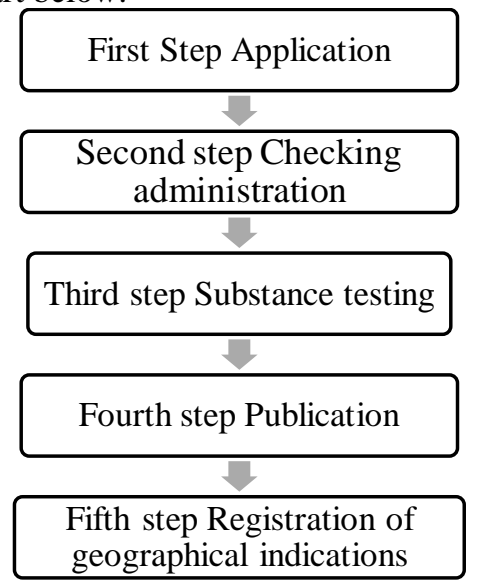

Fig. 1.
Source: Government Regulation Number 51, 2007 concerning geographical indications.
In the above chart, it can be explained in step 1 it requires a maximum of three months, the
second stage, is maximum of three months, the fourth stage is maximum two years, and
releasing a geographical indication certificate is limited to a maximum of two months.

\section{Conclusion}

The arrangement of intellectual property rights in Indonesia had been made since 1885: at, that time, it was the Dutch Indian era. Indonesia had recognized the patent rights, trademark rights, and copyrights. Along with the development of intellectual property rights in Indonesia, it began with the TRIPS Agreement. It is an international agreement about Intellectual Property Rights. If it refers to the TRIPS Agreement on intellectual property rights, all member countries 
are forced to apply an intellectual property system that requires a certain, standard that is considered as high, especially for developing countries. This is in contrast to the intellectual property rights regime of geographical indications, certain commodities and products can get the protection of intellectual property rights due to natural factors, human factors, and a combination of both of them. In 2018, a legal instrument of Indonesia had been significantly advanced. This is evidenced by the many geographical indications which have been registered in the Ministry of Law and Human Rights of the Republic of Indonesia.

Acknowledgments. want to thank Professor Jamal Wiwoho, Najib Immanullah, Ph.D., and Professor Pujiyono from the Faculty of Law of the University of Sebelas Maret Surakarta.

\section{References}

[1] C. Kusmana and A. Hikmat, "Keanekaragaman hayati flora di Indonesia," Journal of Natural Resources and Environmental Management, vol. 5, no. 2, pp. 187-187, 2015.

[2] D. Kusmawan, "PERLINDUNGAN HAK CIPTA ATAS BUKU," Perspektif, vol. 19, no. 2, p. 137, 2014.

[3] R. F. Dewi, P. H. Prihanto, and J. K. Edy, “Analisis penyerapan tenaga kerja pada sektor pertanian di Kabupaten Tanjung Jabung Barat,” E-Jurnal Ekonomi Sumberdaya dan Lingkungan, vol. 5, no. 1, pp. 19-25, 2016.

[4] S. Rongiyati, "Hak Kekayaan Intelektual atas Pengetahuan Tradisional," Negara Hukum: Membangun Hukum untuk Keadilan dan Kesejahteraan, vol. 2, no. 2, pp. 213 238, 2011

[5] A. Sardjono, Intellectual property rights and traditional knowledge. Bandung: PT Alumni, 2006.

[6] Joseph E. Stiglitz, Making Work Globalization Dealing with Globalization Towards a more Fair World (Making Globalization Work), translated by EndrijaniAzwaldi, Bandung: Mizan Library, 2007.

[7] Lili Rasjidi and I.B. Wysa Putra, Law as a System, Bandung: Rusdakarya Teenagers, 1993.

[8] Mimi Hayati and Eliana, Martina, The role of the agricultural sector in the producing district of the Bireuen district of Aceh Province, Jurnal S Pertanian, Aceh, 2017.

[9] Saky Septiono, Protection of Geographical Indications and Potential Geographical Indications in Indonesia, Directorate of Geographical Indications of the Directorate General of Intellectual Property Rights: Ministry of Law and Human Rights of the Republic of Indonesia, 2009.

[10] Sampurno in Kompas: Is a national print media in Indonesia, p. 10, 19 September 2012.

[11] Available from www.WIPO.int (official website of world organization in field of intellectual property right)

[12] Berita nasional di Indonesia yang bereputasi. Available from www.nasional.kompas.com.

[13] Available from www.bps.go.id (official website of Central Statistics Agency of Republic Indonesia).

[14] Available from www.bpkm.go.id (official website of government of Indonesia in field of License and investment).

[15] Available from www.haki.lipi.go.id (official website of lndonesian research government agenc). 